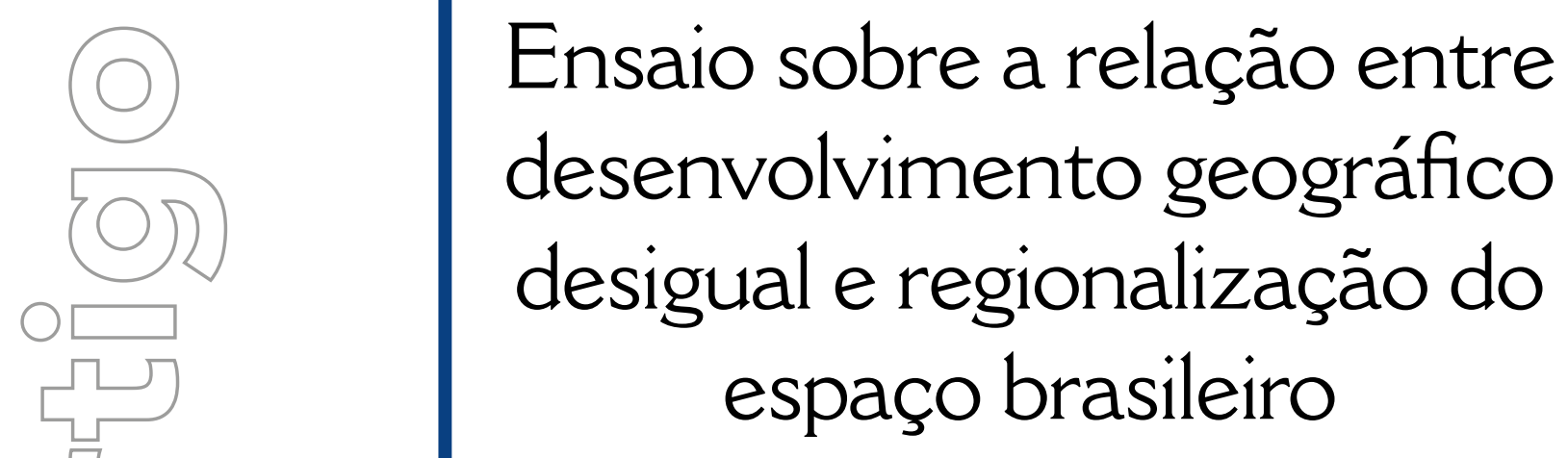

Rita de Cássia Ariza da Cruz

Universidade de São Paulo

São Paulo, SP, Brasil e-mail: ritacruz@usp.br

(1) 0000-0003-4726-5295

\section{revista}

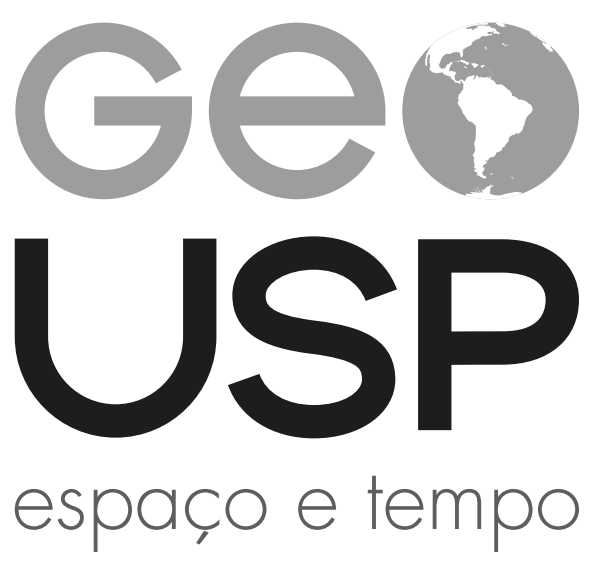

Volume $24 \cdot n^{\circ} 1(2020)$

ISSN 2179-0892 p. $27-50$

Como citar este artigo:

CRUZ, R. C. A. Ensaio sobre a relação entre desenvolvimento geográfico desigual e regionalização do espaço brasileiro. Geousp - Espaço e Tempo (On-line), v. 24, n. 1, p. 27-50, abr. 2020. ISSN 2179-0892.

Disponível em: https://www.revistas.usp.br/geousp/article/ view/155571. doi: https://doi.org/10.11606/issn.2179-0892. geousp.2020.155571.

\section{(c)}

Este artigo está licenciado sob a Creative Commons Attribution 4.0 Licence 


\title{
Ensaio sobre a relação entre desenvolvimento geográfico desigual e regionalização do espaço brasileiro
}

\section{Resumo}

Neste artigo, analisamos a regionalização do espaço brasileiro com base na noção de desenvolvimento geográfico desigual. Partimos de regionalizações de diferentes épocas e autores, fundamentadas em metodologias também diferentes, e, a partir daí, dirigimos o olhar para o processo histórico de produção do espaço brasileiro considerando seus legados espaciais. As noções de totalidade, fragmentação do espaço e configuração geográfica são centrais para esta análise, assim como as noções de divisão territorial do trabalho, forças produtivas e condições gerais de produção. Ao final, sobrepomos cartograficamente informações acerca da distribuição geográfica da força de trabalho no país, a rede rodoviária federal e um indicador de renda, de que resulta um mapa síntese da regionalização do espaço brasileiro.

Palavras-chave: Produção do espaço. Configurações geográficas. Desenvolvimento geográfico desigual. Regionalização. Brasil.

\section{An essay on the uneven neven geographical development and the regionalization of Brazilian territory}

\begin{abstract}
In this article we analyze the regionalization of Brazilian space based on the notion of uneven geographical development. We start from regionalizations of Brazil, from different times and authors, based on different methodologies and from there, we analyze the historical process of production of Brazilian space, considering spatial legacies of this process. The notions of totality, space fragmentation and geographical configurations as well as the notions of Territorial Labor Division, productive forces and production general conditions are central to the analysis undertaken. In the end, we graphically surpass information on the geographic
\end{abstract}


distribution of the workforce in the country, the federal road network and an income indicator, the result of which is presented in a Synthesis Map of Brazilian Space Regionalization.

Keywords: Production of space. Geographical configurations. Uneven geographical development. Regionalization. Brazil.

\section{Ensayo sobre la relación entre desarrollo geográfico desigual y regionalización del espacio brasileño}

\section{Resumen}

En este artículo analizamos la regionalización del espacio brasileño basada en la noción de desarrollo geográfico desigual. Partimos de las regionalizaciones del territorio, de diferentes épocas y autores, basados en diferentes metodologías y desde allí, dirigimos nuestra mirada al proceso de producción histórico del espacio brasileño, considerando los legados espaciales de este proceso. Las nociones de totalidad, fragmentación del espacio y configuraciones geográficas son centrales para el análisis realizado, al igual que las nociones de la División Territorial del Trabajo, las fuerzas productivas y las condiciones generales de producción. Al final, superponemos cartográficamente información sobre la distribución geográfica de la fuerza laboral en el país, la red vial federal y un indicador de ingresos, cuyo resultado se presenta en un Mapa de Síntesis de la Regionalización del Espacio Brasileño.

Palabras clave: Producción del espacio. Configuraciones geográficas. Desarrollo geográfico desigual. Regionalización. Brasil. 


\section{Introdução}

O espaço é um produto da história, com algo outro e algo mais que a história no sentido clássico do termo. Henri Lefebvre, 2008

Regionalizações do espaço brasileiro vêm sendo propostas desde meados do século XIX' com diferentes finalidades, destacando-se, entre estas, a didática (como a divisão regional de Delgado de Carvalho, de 1913) e a metodológica, como as divisões de Milton Santos, de 1999, ou de Ruy Moreira, de 2004, entre outras, e, no caso das regionalizações oficiais, a finalidade da produção de estatísticas, do planejamento ou do ordenamento territorial (como as divisões regionais do Conselho Técnico de Economia e Finanças, de 1939, ou do IBGE, de 1942, 1970 e 1990, por exemplo).

$\bigcirc$ ato de regionalizar pode, portanto, não ter a priori uma aplicação prática, constituindo-se como exercício intelectual que apenas se propugna a concorrer para um melhor entendimento da realidade social e territorial, sendo esse o exato propósito da regionalização objeto deste texto. Nos termos de Haesbaert (2014, p. 95), estaríamos tomando a região como um artifício, um instrumento metodológico, buscando responder a questões analíticas. Sobre o que não existe dúvida é o fato de que o território brasileiro é marcado por um complexo conjunto de diferenças que envolvem desde características naturais - base material original sobre a qual se desenrola a história - até desigualdades socioespaciais, que se revelam em todas as escalas geográficas de análise.

No que tange à natureza e se tratando de uma escala macrorregional, essas diferenças foram objetivamente apontadas por Aziz Ab' Saber no mapeamento dos "Domínios morfoclimáticos brasileiros", de 1965, mais tarde também chamados pelo próprio autor de "domínios de natureza". Segundo Ab'Saber, haveria no Brasil seis grandes domínios (amazônico, cerrado, mares de morros, caatingas, araucárias e pradarias), majoritariamente separados por faixas de transição. No decorrer do tempo, essa base material natural, originalmente muito pouco transformada pelos povos que aqui viveram e viviam no momento da colonização, foi cedendo lugar a paisagens cada vez mais humanamente produzidas. Como afirmara Moraes (2008, p. 70) acerca dos processos de colonização em geral:

A colonização pode, finalmente, ser equacionada como um processo de valorização do espaço, realizando todas as modalidades já descritas de tal relação: apropriação de meios naturais, transformação de tais meios numa segunda natureza, apropriação destes meios naturais transformados, produção de formas espaciais, e apropriação do espaço produzido.

A importância que tiveram e têm as características naturais do território nos arranjos espaciais historicamente produzidos é reconhecida, em maior ou menor grau, por todos aqueles

1 De acordo com Guimarães (1941), em 1843, Friedrich Phillip Von Martius propôs uma divisão regional do Brasil indicando o estudo da história do país, de forma pioneira, com base em "grupos regionais". 
que se propuseram a regionalizar o Brasil desde o século XIX. Situado no plano das ideias, esse processo revela a progressiva importância, ao longo do tempo, dos critérios sociais e econômicos para a definição de grandes regiões brasileiras, ao contrário das primeiras regionalizações (sobretudo do fim do século XIX e das primeiras décadas do XX), fortemente influenciadas pelo método positivista e, consequentemente, pelo peso atribuído à natureza no entendimento dos arranjos socioespaciais no território.

Não queremos com isso dizer que a natureza não desempenha nenhum papel na definição do desenvolvimento geográfico desigual, mas sim que não se the pode atribuir sua razão de existir. Ao lado do valor da força de trabalho, dos custos de insumos intermediários, dos níveis de demanda efetiva, entre outros aspectos atuando conjuntamente, a "generosidade da natureza" influi diretamente na definição da "vantagem de uma localização para o capitalista" (Harvey, 2013, p. 495). A natureza sozinha, entretanto, pouco explica, encontrando-se no desenvolvimento geral das forças produtivas (basicamente força de trabalho humana e meios de produção) e nas condições gerais de produção ${ }^{2}$ um caminho analítico que nos permite dialetizar sua eventual "generosidade".

Já na segunda metade do século XX, destacam-se algumas leituras do território brasileiro traduzidas numa regionalização de seu espaço (Mapas 1-A, 1-B, 1-C e 1-D).

Uma delas, jamais cartografada, é a de Jacques Lambert (1901-1991), ${ }^{3}$ que, pautado no reconhecimento da profunda desigualdade existente entre as porções sul-sudeste e norte-nordeste do país, vislumbrou, em 1953, a existência de "dois Brasis". Pouco mais de uma década depois, ${ }^{4}$ em 1964, Pedro Pinchas Geiger (1922-) definiu três regiões geoeconômicas, baseando-se na história da formação territorial e "nos efeitos da industrialização" no território brasileiro. Fundado na noção de divisão territorial do trabalho (DTT), Roberto Lobato Corrêa (1939-) identificou, em sua proposta de regionalização de 1989, o que ele chamou de "três Brasis" (bastante semelhante à regionalização de Geiger, com a diferença de haver optado por respeitar os limites estaduais) (Corrêa, 1989). Em 1999, Milton Santos (1926-2001) propôs a existência de "quatro Brasis", levando em conta a geografização do meio técnico-científico-informacional pelas diferentes regiões brasileiras definidas pelo IBGE (Santos; Silveira, 2001). Por fim, em 2004, Ruy Moreira (1941-) identificou "tendências de regionalização" 5 relativas à DTT e o fez rompendo com os paradigmas das propostas anteriores, desrespeitando limites estaduais, sobrepondo regiões e definindo regiões não contíguas.

2 De acordo com Lencioni (2007, p. 5), as condições gerais de produção articulam o particular ao geral e podem ser agrupadas em dois conjuntos: "o primeiro dizendo respeito àquelas condições que mantêm conexão direta com o processo de produção" e circulação do capital (como bancos, alguns serviços e redes de circulação material e imaterial) e o segundo "relativo àquelas condições cuja conexão com o processo de produção e circulação são indiretas" (como escolas, hospitais e centros de lazer, esportivos e culturais, a titulo de exemplo).

3 No livro Os dois Brasis, de 1957, originalmente editado na França em 1953, com o título Le Brésil: structures sociales et institutions politiques.

4 Durante o período em que trabalhava no IBGE.

5 Essa proposta de regionalização está originalmente no texto "A nova divisão territorial do trabalho e as tendências de configuração do espaço brasileiro", do livro Brasil século XXI, por uma nova regionalização", publicado pelo PPGEO-UFF em 2004. Para este artigo, entretanto, baseamo-nos no capítulo de mesmo nome e também de Ruy Moreira (2014). 


\section{Mapa 1 - Regionalização do espaço brasileiro segundo (A) Pedro Pinchas Geiger (1964), (B) Roberto Lobato Corrêa (1989), (C) Milton Santos (1999) e (D) Ruy Moreira (2004)}

A

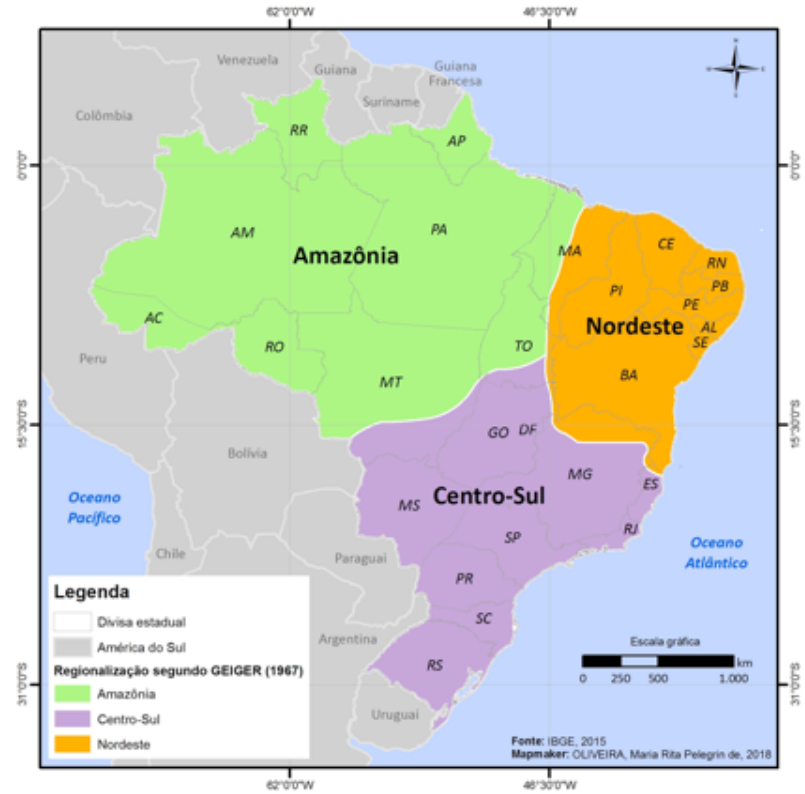

C

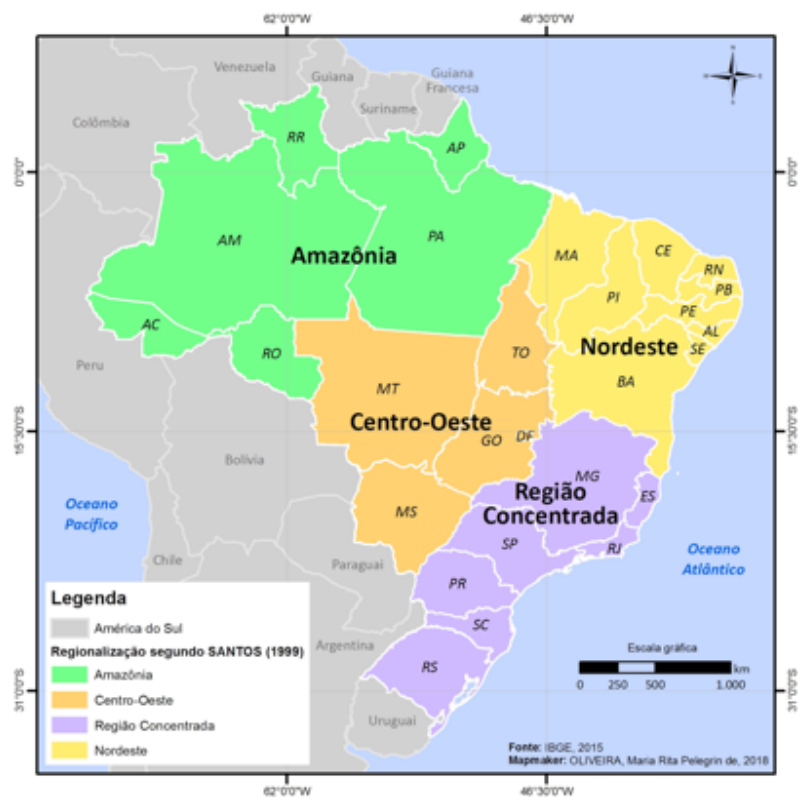

B

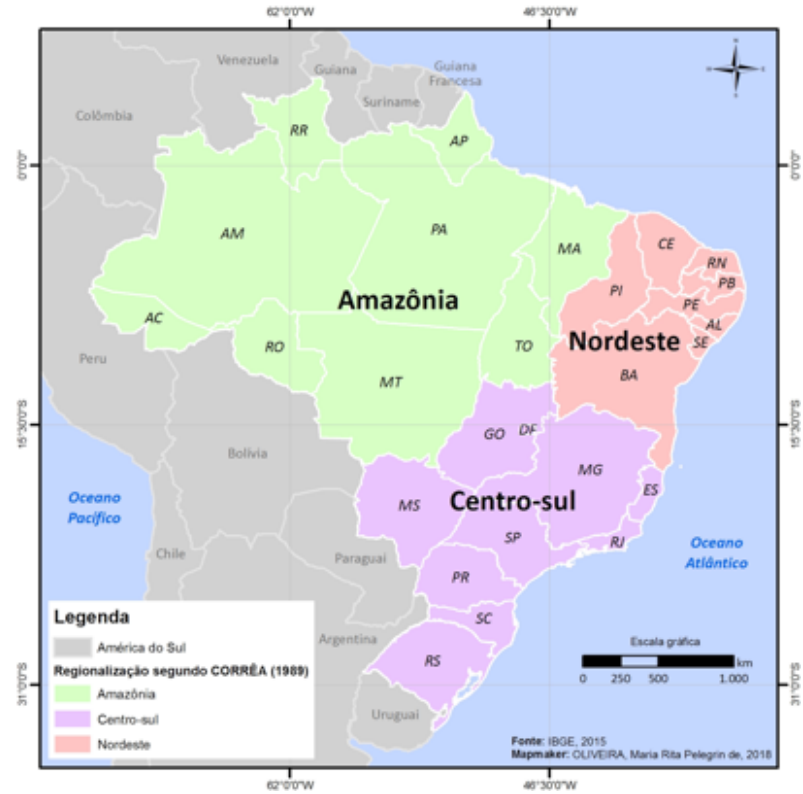

D

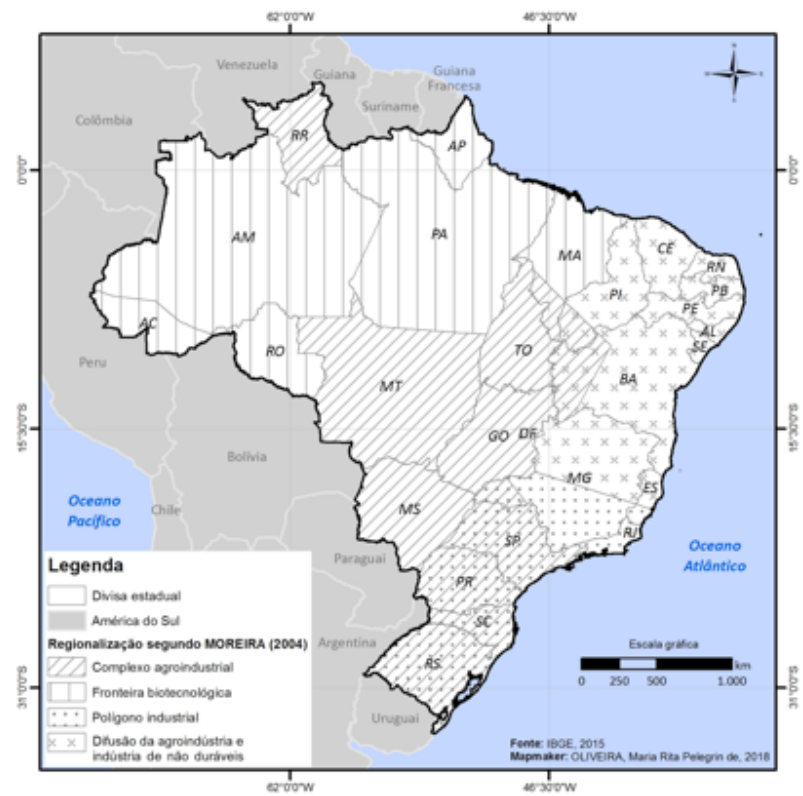

Embora nenhum desses autores tenha proposto regionalizar o Brasil a partir da noção de desenvolvimento geográfico desigual é notório que suas regionalizações expressam, claramente, o entendimento de que os processos socioeconômico-espaciais que marcaram e marcam o território brasileiro produziram desigualdades que se manifestam, também, em uma escala regional.

\section{Pressupostos teóricos e metodológicos}

Com o objetivo de nos aproximarmos de uma interpretação plausível da regionalização do espaço brasileiro, fundamos nossa análise nas noções de totalidade, de desenvolvimento 
geográfico desigual, de produção do espaço e de configuração geográfica ou espacial. Com a noção de totalidade, pretendemos demarcar nossa visão de que o Estado-nação brasileiro pode ser compreendido como uma totalidade em si ao mesmo tempo em que é contido pela totalidade-mundo, ambas totalidades abertas e em movimento (Lefebvre, 1955; Lencioni, 2015b).

A partir do preposto acima, delimitamos uma primeira opção de método, qual seja, a de evitar expressões metafóricas como dois, três ou quatro Brasis, as quais, se, por um lado, iluminam as profundas diferenças que marcam a nação brasileira, por outro, podem ofuscar as dimensões dialética e contraditória que a caracterizam como uma totalidade una. Naturalmente, os autores que as propuseram estavam cientes desse risco. Por exemplo, Milton Santos e María Laura Silveira (2001, p. 268), enunciam sua proposta nos seguintes termos: "poderíamos assim, grosseiramente - e como sugestão para um debate - reconhecer a existência de quatro Brasis".

Por outro lado, pensando o lugar do Brasil no movimento da totalidade-mundo e as relações que se estabelecem entre a escala global e a escala da nação-Estado, é na noção de desenvolvimento geográfico desigual que encontramos guarida. Considerando o espaço como sendo social e historicamente produzido, nos termos de Lefebvre (2008, p. 55/57), ou seja, de que "vemos no espaço o desenvolvimento de uma atividade social", pois "toda sociedade produz um espaço", é preciso reconhecer que as contradições do espaço não adviriam "de sua forma racional, tal como se revela nas matemáticas. Elas advêm de seu conteúdo prático e social e, especificamente, do conteúdo capitalista".

Nesse sentido, entendemos também que, tal como coloca Milton Santos (1997), do processo social e histórico de produção do espaço resultam distintas configurações geográficas ou espaciais. Essas configurações são refeitas pelas sociedades a cada momento, seja do ponto de vista de sua existência material, seja no que concerne a seus usos, seus sentidos e seus significados. As configurações geográficas ligam-se umbilicalmente às geografias produzidas pelo processo de espacialização das forças produtivas e das condições gerais de produção no território. Como afirma Santos (1997, p. 2), "cada lugar está sempre mudando de significação, graças ao movimento social: a cada instante as frações da sociedade que the cabem não são as mesmas".

Partindo do pressuposto de Milton Santos e aplicando-o à escala regional, podemos dizer que, além de datada historicamente, toda regionalização será sempre uma tentativa de refletir uma realidade em permanente transformação. Para Harvey (2013, p. 479), "a produção de configurações espaciais pode então ser tratada como um momento ativo dentro da dinâmica temporal geral da acumulação e da reprodução social". Isso porque a transformação radical das relações sociais, que deriva da subordinação formal da atividade humana ao capital, como afirma o autor, não ocorreu de forma regular. Segundo Harvey (2013, p. 477), "ela se moveu mais rápido em alguns lugares do que em outros", tendo "resistido mais fortemente aqui e sido mais bem-vinda ali".

Assim, é no entrelaçamento entre totalidade-mundo em movimento, desenvolvimento geográfico desigual, produção do espaço e configurações geográficas que embasamos nossa reflexão, compreendendo que é desse entrelaçamento que resultam fragmentações do espaço total da nação-Estado Brasil, as quais têm sido expressas por meio de propostas de regionalização, tal como fizeram Geiger, Corrêa, Santos e Moreira, entre tantos outros. 


\section{O desenvolvimento geográfico desigual à brasileira}

Se o desenvolvimento geográfico desigual é, por um lado, compreendido, desde os primórdios do século XX, por pensadores como Lenin, Trotsky, Novack e Mandel, como uma determinação do modo de produção capitalista, o espaço, por outro lado, não é um mero receptáculo das ações humanas. Pelo contrário, há uma relação dialética entre sociedade e espaço, "um se realizando no outro e através do outro", indicando a "imanência da produção do espaço no processo de constituição da sociedade" (Carlos, 2011, p. 53).

É nesse sentido que nos remetemos não apenas ao desenvolvimento geográfico desigual manifesto no território brasileiro, mas também a um desenvolvimento geográfico desigual que chamamos de "à brasileira", ou seja, caracterizado por particularidades do processo de produção do espaço que fazem do Brasil um caso único, ainda que profundamente marcado por determinações históricas gerais, do passado e do presente.

A formação socioespacial brasileira, cuja história remete à própria gênese do modo de produção capitalista, é uma expressão concreta das transformações políticas, econômicas, socioculturais e espaciais pelas quais passou o mundo nos últimos cinco séculos, mas também é um retrato único de si mesma, como toda formação socioespacial. Abrigo de ordens distantes, o território brasileiro segue revelando suas contradições internas, ao mesmo tempo universais e particulares.

Ao refletir sobre a história colonial do país, vale dizer que se, por um lado "à colônia corresponde a existência de uma metrópole", por outro, "cada país colonizador possui a sua geopolítica metropolitana" (Moraes, 2008, p. 63-64). Mais ainda, essa geopolítica não é indiferente aos territórios colonizados. Ao contrário, como afirma Prado Jr. (2017, p. 15), há um certo "sentido da colonização", pois " todo povo tem na sua evolução, vista à distância, um certo "sentido", o qual "se percebe não nos pormenores de sua história, mas no conjunto dos fatos e acontecimentos essenciais que a constituem num largo período de tempo".

Como afirma Moraes (1999, p. 31), "todos os fluxos de colonização do Novo Mundo partiram de centros de difusão assentados na costa, que articulavam a hinterlândia explorada com as rotas oceânicas que alavancavam tal exploração". E, ainda no dizer do autor, a formação territorial do Brasil teria sido típica no que tange à "reiteração desse padrão colonial". É o que, em certo sentido, também afirma Andrade (2004, p. 35): "O sistema colonial organizou o espaço de forma a que nele se fizesse a exploração das áreas ricas em produtos de interesse no mercado europeu, ligando estas áreas a portos que desempenhavam a função de relais entre a hinterlândia e a metrópole".

Moreira (2014, p. 32-33) fala num "modelo brasileiro de acumulação", que difere do europeu, dado que se assenta em "um sistema agrícola montado pelo e em função do modo de produção, o colonial agroexportador, constituído basicamente de dois sub-setores articulados: a grande empresa agro-mercantil e a pequena lavoura de subsistência". Contrapondo esse ao modelo clássico de acumulação, Moreira (2014, p. 37) afirma que, por ser "uma economia colonial de grandes empresas agroexportadoras movidas inicialmente pelo trabalho escravo e a seguir por formas de relações de trabalho de cunho clientelista [...], o quadro estrutural e conjuntural em que evolui a urbano-industrialização é distinto daquele da Europa". 
Todavia, ao longo de mais de cinco séculos de história, o território brasileiro foi sendo reconfigurado entre heranças de um passado mais remoto e outras de tempos mais recentes, amalgamadas a processos contemporâneos, atrelados a lógicas próprias de um desenvolvimento geográfico desigual, tal como descrito por Harvey e Smith. Os Mapas 2, 3, 4-A, 4-B e 5 expressam, em parte, esses legados territoriais e as configurações geográficas deles decorrentes.

\section{Divisão territorial do trabalho, desenvolvimento geográfico desigual e configurações geográficas}

A organização do território brasileiro em municípios é indicativa da profunda diferença, em termos de divisão político-administrativa, entre suas porções ocidental e oriental, esta última muito mais sub-dividida que a outra. Como se pode notar no Mapa 2, é uma característica marcante das regiões Norte e Centro-Oeste a existência de municípios com territórios significativamente extensos em relação às dimensões territoriais de muitos localizados no que chamamos de "porção oriental do país". Essa divisão político-administrativa sugere também uma história territorial marcada por sucessivas divisões territoriais do trabalho e pelo desenvolvimento geográfico desigual das condições gerais de produção, das quais decorrem outras diferenças espaciais e configurações geográficas.

Ressalte-se o fato de que, por mais de três séculos, o Brasil foi uma colônia de exploração, a qual, tal como outras colônias nessa condição, devia "seu dinamismo às possibilidades de acumulação” (Moraes, 2008, p. 67) que propiciava à metrópole .

\section{Mapa 2 - Brasil: divisão municipal}

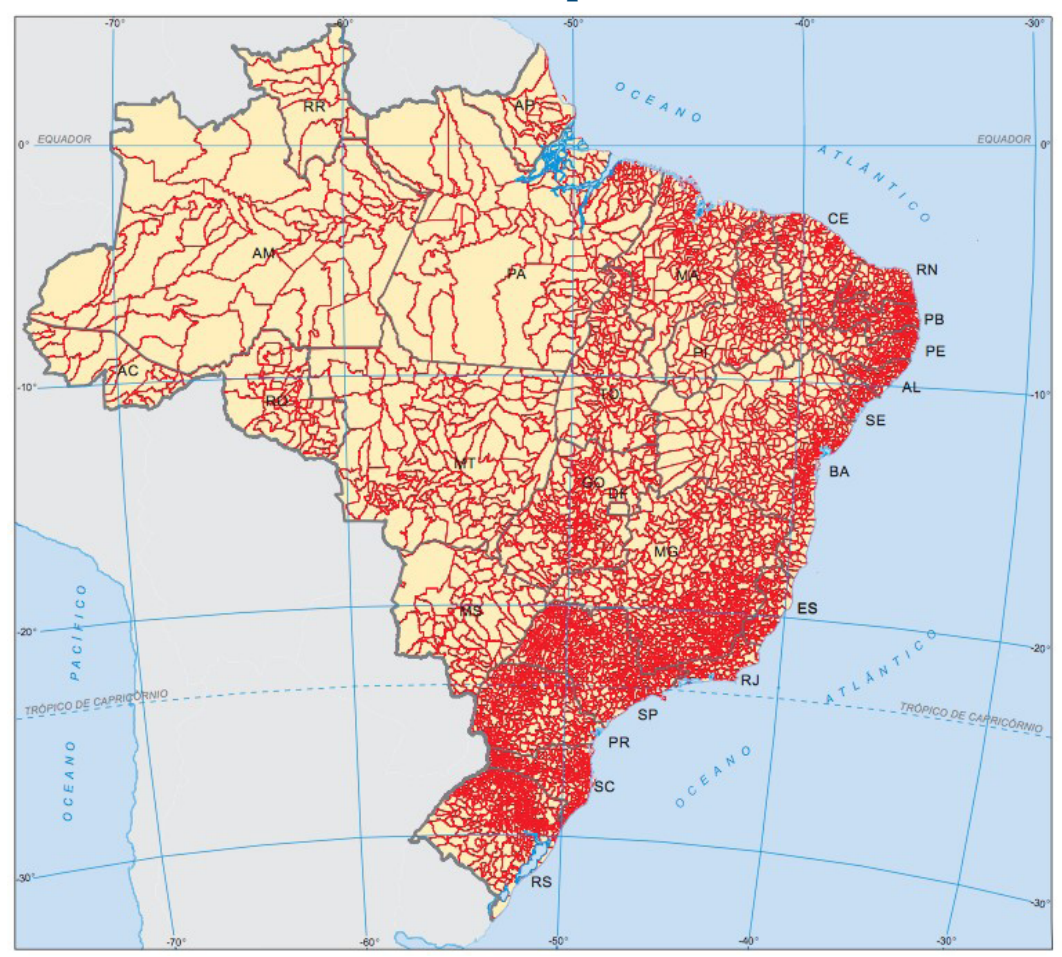

Total de municípios: 5570

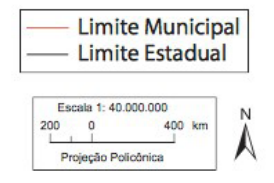

fonte: Evolução da malha municipal ([2018?]).

Pela importância econômica que adquirira com a produção de cana-de-açúcar, a zona da mata nordestina teve um povoamento precoce em relação ao restante do território colonial. É nesse 
mesmo sentido que a região aurífera das "Minas Geraes" e outras destinadas à criação de gado, entre outras regiões coloniais, resultaram em fixação populacional e no surgimento de povoados, muitas vezes alçados à condição de freguesias e de vilas, ${ }^{6}$ de acordo com a legislação territorial vigente.

Uma segunda característica marcante da história territorial brasileira reside no fato de ter cabido a Portugal, desde o Tratado de Tordesilhas (1494), a extensa faixa de terras entre esta linha imaginária e o atual litoral brasileiro. Como coloca Prado Jr. (2017, p. 35), visando ocupação e defesa eficientes, a dispersão do povoamento da colônia obrigou os colonizadores "a encetar a colonização simultaneamente em vários pontos dela", sendo esse o motivo da adoção do sistema de capitanias hereditárias (de 1530), como se sabe, formado originalmente por 15 faixas de terra traçadas da costa até a linha imaginária de Tordesilhas.

De acordo com Moraes (2008, p. 69), formavam-se nas colônias, de um modo geral, "zonas de difusão", que o autor considera "núcleos de assentamento original que servem de base para os movimentos expansivos posteriores". No caso brasileiro, esses núcleos foram primeiramente litorâneos; ainda no século XVI, chegaram ao planalto, como é o caso da Vila de São Paulo de Piratinynga, fundada em 1560, e, nos séculos seguintes, foram adentrando o território para muito além dos limites previstos por Tordesilhas.

A economia extravertida que caracterizou a colônia também favoreceu localidades litorâneas com função portuária, contribuindo para consolidar um padrão espacial de ocupação territorial costeira. Como resultado, chegamos ao século XIX, como apontara Prado Jr. (2017, p. 34), com uma população distribuída de forma bastante irregular pelo território ainda colonial:

Núcleos apenas, alguns bastantes densos, mas separados uns dos outros por largos vácuos de povoamento ralo, se não inexistente. $\bigcirc$ seu aspecto geral, guardadas naturalmente as devidas proporções quantitativas, é mais ou menos o mesmo de hoje. Há uma flagrante semelhança entre a distribuição do povoamento naquele princípio do século XIX e a de nossos dias. Salvo o adensamento posterior, a estrutura geral do povoamento continua mais ou menos a mesma; excetua-se apenas a remodelação que sofreram o Sul e o Centro-Sul do país, bem como esta região dos altos afluentes do Amazonas, que hoje formam o território do Acre, e que não fazia ainda parte do Brasil, nem se achava ocupada.

$\bigcirc$ que se passa nos séculos seguintes definitivamente não desfaz completamente o quadro territorial-demográfico descrito acima. Pelo contrario, ele é reforçado por novos processos econômicos da nação independente, com grande concentração espacial e centralização de capitais promovidas pela atividade cafeeira e pelo processo de industrialização, beneficiando sobretudo, como se sabe, estados das atuais regiões Sul e Sudeste do país. Embora os escritos originais de Prado Jr. remetam à década de 1940 e a despeito de um recente processo de interiorização, a população brasileira em geral e a população economicamente ativa (PEA) seguem distribuídas territorialmente de forma bastante irregular, com uma clara concentração na porção oriental (Mapas 7 e 8).

6 A partir de 1891, chamados, respectivamente, de distritos e municípios. 


\section{Mapa 3 - Brasil: densidade demográfica - 2010}

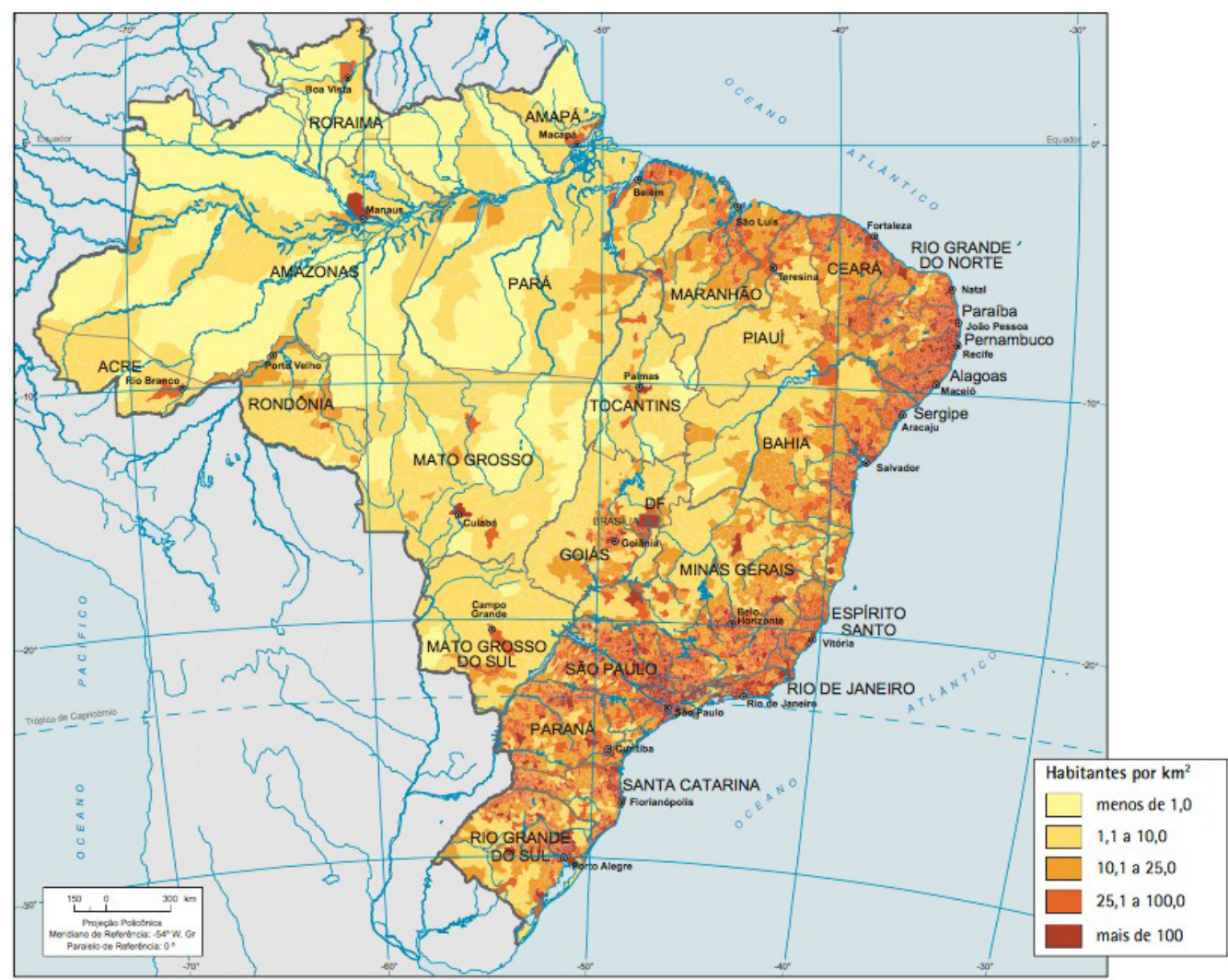

fonte: Densidade demográfica ([2012?]).

No que tange às configurações geográficas propriamente ditas, optamos metodologicamente por abordar dois aspectos que consideramos estruturantes: a distribuição espacial da indústria e a rede de circulação.

Quanto à indústria, nossa escolha se justifica pela relevância dessa atividade econômica na organização do espaço brasileiro a partir do fim do século XIX. No dizer de Moreira (2014, p. 250), a industrialização representou uma "ruptura na forma histórica de relação sociedade-espaço no Brasil" em relação aos séculos anteriores. E, mais do que isso, o processo de industrialização reorganizou o país regionalmente. Como afirma o autor ao se referir às décadas de 1950-70, "[...] a revolução industrial brasileira desigualiza a estrutura industrial a favor de São Paulo, subsidiariamente dos estados do Rio de Janeiro e Minas Gerais [...]” (Moreira, 2014, p. 257).

Nas décadas seguintes, a despeito da restrutração industrial pela qual passou o país, envolvendo desconcentração espacial e perda relativa de importância da indústria na composição do PIB nacional (Lencioni, 2015a), é preservada a hegemonia industrial da região Sudeste tanto no que toca ao volume da produção quanto no valor envolvido e no número de pessoas empregadas.

Ao analisar "o novo mapa da indústria" brasileira no início do século XXI, Lencioni (2015a, p. 31) fala da importância da inovação na atividade industrial e, entre outras conclusões, afirma que:

[...] os estabelecimentos industriais que implantaram inovação de produto e/ou processo concentram-se, em especial, no Sul-Sudeste do Brasil, particularmente, no estado de São Paulo. Retrata-se, assim, uma grande desigualdade quanto à distribuição territorial das indústrias inovadoras, aquelas com maiores possibilidades 
de gerar riqueza. Até porque [...] são as de maior porte. E é sabido, também, que elas têm maior potencial de mercado. Do ponto de vista da inovação na atividade industrial, somos um país muito desigual.

Os Mapa 4-A e 4-B expressam a concentração tanto da atividade industrial em geral como das atividades intensivas em conhecimento na porção oriental do território, corroborando a leitura de Milton Santos quanto à existência de uma "região concentrada", formada pelas regiões Sudeste e Sul.

\section{Mapa 4 -Brasil: (A) empresas industriais (2016) e (B) distribuição concentrada das atividades intensivas em conhecimento por estado em 2009-2011}

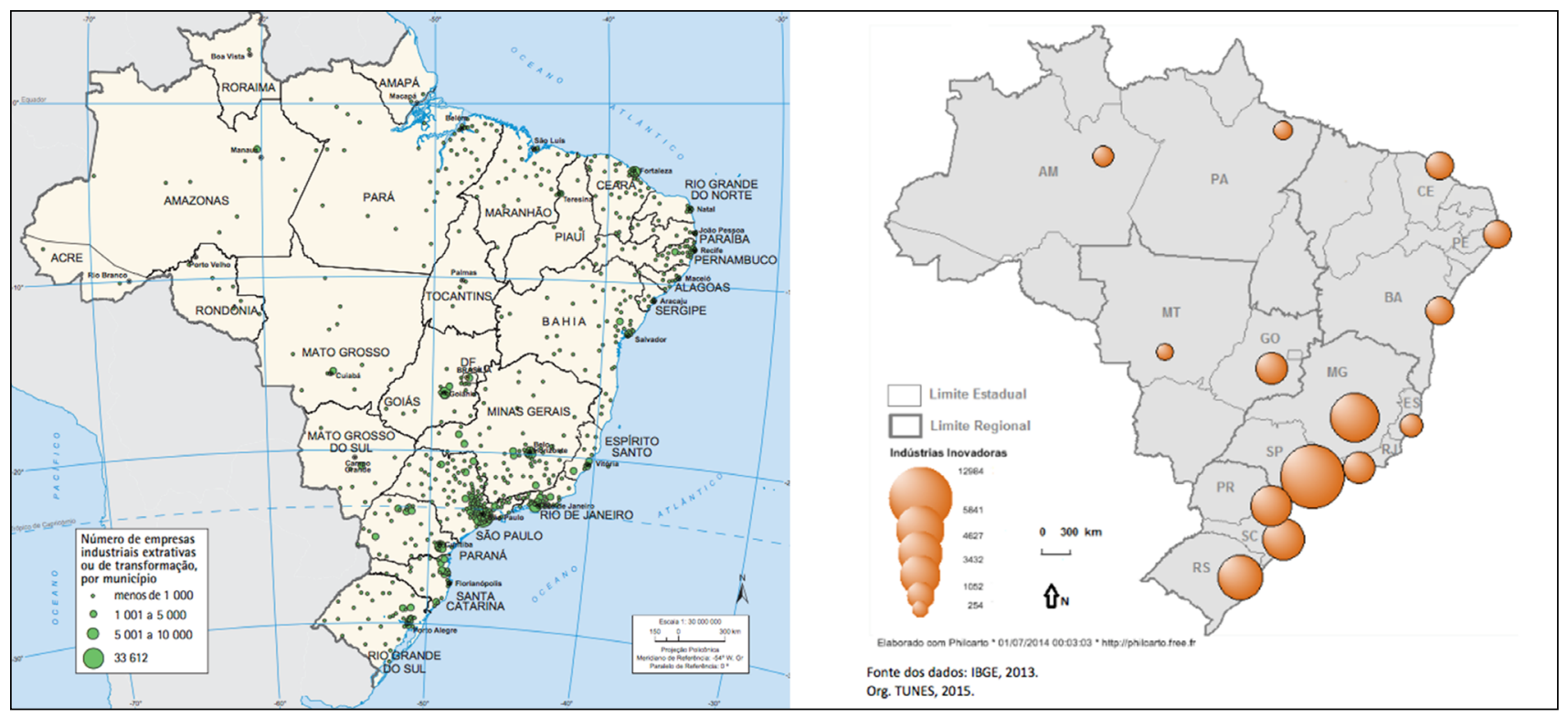

fontes: Mapa 4-A: Empresas industriais ([2008]); Mapa 4-B: Tunes (2015).

Quanto às infraestruturas de circulação, compreendidas como parte importante das condições gerais de produção, afirmam Santos e Silveira (2001, p. 261) que "hoje não basta produzir", pois seria uma característica do presente momento "a necessidade de criar condições para maior circulação dos homens, dos produtos, das mercadorias, do dinheiro, de informação, das ordens etc." , o que se traduz na "criação ou aperfeiçoamento dos sistemas de engenharia que facilitam o movimento". Conforme Santos (1996, p. 219), "é indispensável pôr a produção em movimento, pois agora é a circulação que preside à produção".

Por outro lado, afirmam Santos e Silveira (2001, p. 261/262), o processo de criação de fluidez em países de maior extensão territorial e com grandes disparidades regionais e de renda "é seletivo e não igualitário", sendo orientado, basicamente, por "nexos econômicos, sobretudo os da economia internacional".

As infraestruturas de circulação (de mercadorias, de pessoas, de informação) acompanham a concentração demográfica, urbana e industrial que caracteriza o território brasileiro, como expresso no Mapa 5. Essas infraestruturas formam verdadeiras redes técnicas (Santos, 1996), as quais, na atualidade, segundo Arroyo (2015, p. 42), "enquanto sistemas de 
engenharia modernos e complexos transmitem valor às atividades que delas se utilizam [...] os lugares melhor dotados dessas infraestruturas serão mais disputados entre as empresas que entram no jogo da competitividade".

\section{Mapa 5 - Brasil: redes de transporte - 2014}

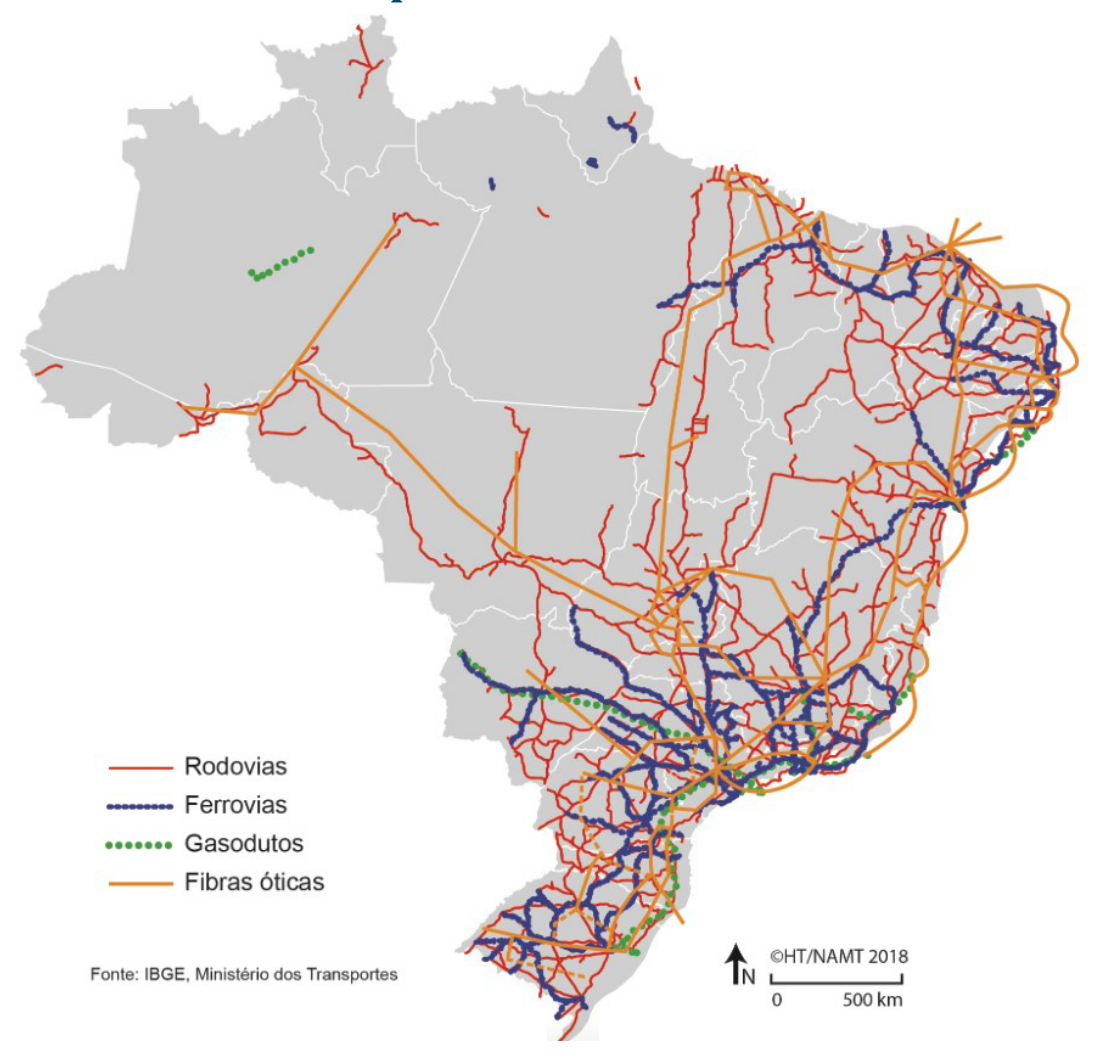

fonte: Théry; Mello-Théry (2018).

As configurações geográficas produzidas pelas redes de circulação devem ser compreendidas, portanto, para além de sua simples materialidade e sim como expressões, no território, do poder das empresas e do Estado. Como afirma Arroyo (2015, p. 42-3), "caminhos, estradas de ferro, canais, rios dragados são entendidos como linhas de poder estratégico que configuram os territórios", sendo central a participação do Estado no traçado, na construção e na gestão da infraestrutura de transporte e comunicação. Para Lencioni (2007, p. 6), ao permitir a circulação da mercadoria e, consequentemente, sua realização no mercado, as redes de circulação em conexão direta com o processo produtivo acabam sendo equipamentos prioritários em detrimento "de equipamentos coletivos de consumo relacionados indiretamente ao processo de produção".

Naturalmente, o conjunto de aspectos abordados nesta seção (divisão político-administrativa municipal, densidade demográfica, indústria e redes de circulação) tem uma existência profundamente imbricada, além de só poder ser compreendido se se considerar sua natureza social e histórica e, consequentemente, conflituosa e contraditória. Assim, a sequência de mapas apresentados poderia levar a pensar na existência de "dois Brasis", não nos termos de Jacques Lambert, dado que o autor apontou uma divisão entre norte-nordeste, regiões economicamente menos desenvolvidas, e uma porção sul-sudeste, mais desenvolvida e próspera. Em verdade, 
o que nos sugerem os Mapas 4-A, 4-B e 5, assim como os Mapas 2 e 3, é a existência de um país cindido entre uma porção oriental, concentradora da força de trabalho, mais bem dotada de objetos técnicos relativos à atividade industrial e à circulação de pessoas e de mercadorias, onde forças produtivas e condições gerais de produção se apresentam, portanto, mais densas, e outra porção ocidental, com um território bem menos fragmentado do ponto de vista político-administrativo, menos fluído (Santos; Silveira, 2001) e menos denso no que tange à demografia, assim como à presença de capital fixo relativo a atividades industriais como sistemas de engenharia que dão suporte à circulação (onde, consequentemente, as condições gerais de produção encontram-se menos desenvolvidas). Embora não retratadas nos mapas, são bastante conhecidas as profundas diferenças entre as porções leste e oeste do país no tocante à estruturação de sua rede urbana, dada a forte concentração demográfica na porção oriental do território nacional.

Se, entretanto, por um lado, as configurações geográficas do território brasileiro sugerem um sentido longitudinal de sua fragmentação, a análise de aspectos socioeconômicos aponta, efetivamente, outro sentido, latitudinal (como indicara Lambert), em que as regiões Norte e Nordeste se destacam por seus indicadores sociais, piores que os apresentados pelas regiões Centro-Oeste, Sudeste e Sul. E é desse aspecto que tratamos no próximo tópico.

\section{A desigualdade social e territorial brasileira}

A despeito das sete décadas que separam a análise de Jacques Lambert e o momento atual e não obstante as políticas distributivas de riqueza e de renda das últimas décadas, o Brasil segue sendo um país bastante desigual e as diferenças sociais entre norte e sul são reafirmadas por estudos recentes. Nesse sentido, primeiramente, precisamos demarcar nosso entendimento, com base em Arretche (2015, p. 194), de que a desigualdade não se restringe à renda, pois, no caso do acesso a serviços, por exemplo, "pessoas com mesmos ganhos podem ter padrões de vida muito diferentes caso tenham distinto acesso".

Segundo Arretche (2015, p. 195), no processo recente (entre 1970 e 2010) de expansão das coberturas de acesso a serviços essenciais (água, esgoto e energia elétrica) no Brasil, houve melhora generalizada dos indicadores. Porém, ressalta que "quando o ponto de partida são taxas muito baixas [...] pode mesmo ocorrer aumento das desigualdades, se essa expansão for concentrada em algumas jurisdições e outras forem deixadas para trás".

Apesar da melhora generalizada nos indicadores de desigualdade do período, a desigualdade de riqueza, medida pelo PIB per capita, "permaneceu rigorosa e escandalosamente estável". Além disso, aumentou a desigualdade entre os municípios brasileiros no que tange à concentração da pobreza, "medida pelo percentual de indivíduos vivendo com renda inferior a meio salário-mínimo" (Arretche, 2015, p. 196).

Baseada nos dados dos Censos Demográficos de 1970, 1980, 1991, 2000 e 2010, Arretche (2015, p. 201, grifo do original) conclui que "a redução da pobreza e da desigualdade de renda teve desigual distribuição territorial, aumentando a distância entre áreas com menor e maior concentração de pobres". As mais altas taxas de pobreza, aponta, "estão concentradas 
na região Nordeste e em parte das regiões Norte e Sudeste" e essa geografia espelha uma "alta desigualdade territorial" no país (Arretche, 2015, p. 204).

Mapeamento realizado por Théry e Mello-Théry (2018) (Mapa 6-A) dá conta, igualmente, de um país cindido em norte e sul no que tange ao rendimento nominal médio mensal. Segundo Guerra, Pochmann e Silva (2014, p. 11), "no Brasil, assim como na América Latina, a primeira década do século XXI trouxe consigo o retorno do crescimento econômico combinado com a redução da pobreza e da desigualdade social". Porém, continuam os autores, "não obstante o protagonismo da região, persegue ainda formas antigas e modernas de manifestação da exclusão social" (Guerra; Pochmann; Silva, 2014, p. 12).

Baseado no Atlas de Desenvolvimento Humano no Brasil, desenvolvido pelo Programa das Nações Unidas para o Desenvolvimento (Pnud), pelo Instituto de Pesquisa Econômica Aplicada (Ipea) e pela Fundação João Pinheiro (FJP), Boscariol (2017) identifica também uma certa fronteira regional entre uma porção norte e uma porção sul do país, tendo esta última um melhor desempenho que a primeira no que tange ao índice de desenvolvimento humano municipal (IDHM). Essa diferença entre territórios mais ao norte e outros a sul permanece, a despeito do crescimento generalizado do IDHM para a quase totalidade dos municípios brasileiros e da diminuição das diferenças intra e inter-regionais entre 2000 e 2010 (Boscariol, 2017).

Cabe ainda dizer que os autores citados neste artigo são unânimes em reconhecer que a desigualdade social no Brasil se manifesta em diferentes escalas, ou seja, os melhores indicadores alcançados por Sul e Sudeste não apagam uma realidade contraditória, intrarregional, segundo a qual, mesmo onde figuram os melhores indicadores de riqueza e de renda, existem inúmeras situações de pobreza ou de exclusão (Guerra; Pochmann; Silva, 2014).

\section{Mapa 6 - Brasil: (A) valor do rendimento nominal médio mensal (2010) e (B) distribuição espacial do IDHM no território nacional (2010)}

A

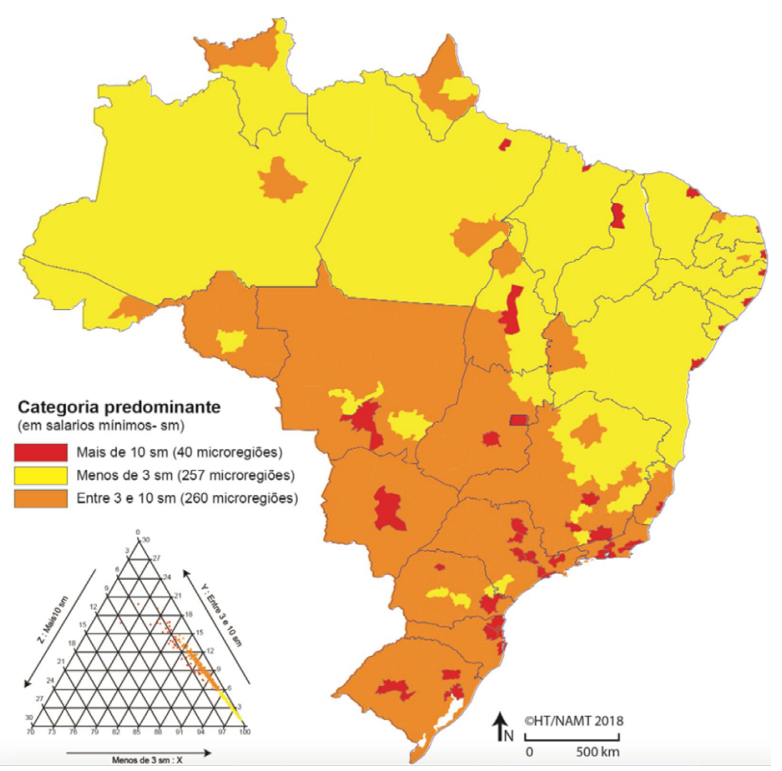

B

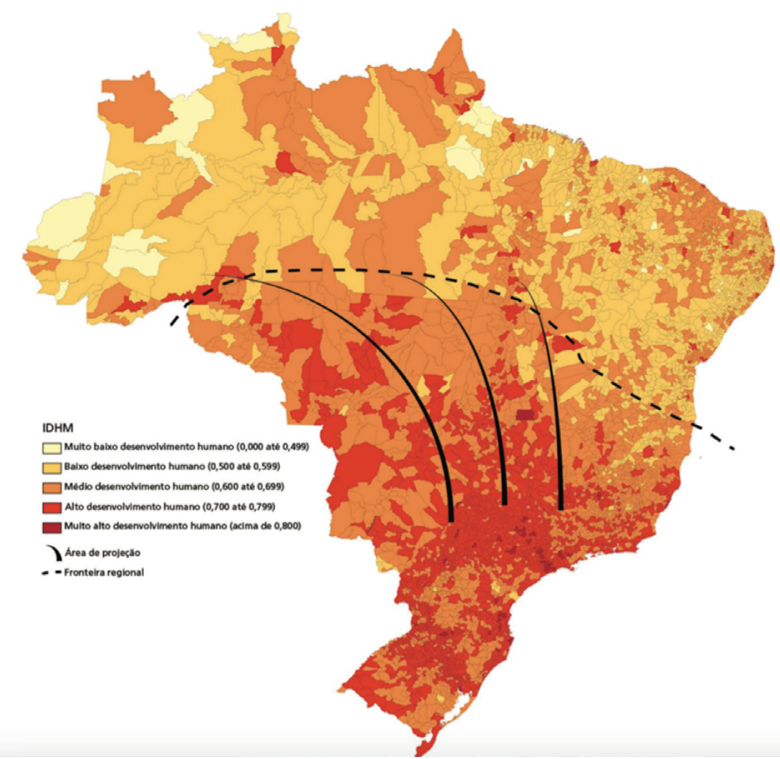

fontes: Mapa 6-A: Théry; Mello-Théry (2018); Mapa 6-B: Boscariol (2017). 
Por outro lado, a cartografia da exclusão social no Brasil (Mapas 6-A e 6-B), assim como as análises de diferentes pesquisadores organizadas por Arretche (2015), não deixa dúvidas de que o Brasil permanece um país cindido, no que tange a indicadores socioeconômicos, entre uma porção norte e uma porção sul, além das diferenças profundas que caracterizam internamente cada uma dessas grandes porções do território nacional.

\section{Desenvolvimento geográfico desigual e regionalização do espaço brasileiro}

Como exposto até aqui, o desenvolvimento geográfico desigual em território brasileiro manifesta-se de diferentes formas, entre as quais destacamos, de um lado, as configurações geográficas, que espelham a desigual distribuição espacial das condições gerais de produção pelo território nacional, as quais, por sua vez, são resultantes das relações sociais de produção no desenrolar de processos históricos, sociais e econômicos materializados no território. Além disso, o desenvolvimento geográfico desigual não pode ser descolado da desigualdade de renda como dimensão da iniquidade em sentido amplo.

É importante também demarcar que compreendemos que as configurações geográficas não são apenas marcas do passado e do presente cristalizadas no espaço, posto que representam possibilidades para o futuro, ao assumir o papel de vantagens comparativas na encarniçada disputa por investimentos.

Assim, é considerando o encontro entre essas dimensões tangível e intangível do desenvolvimento geográfico desigual (distribuição espacial da população em geral e da força de trabalho, especificamente, configurações geográficas e renda) no processo histórico de produção do espaço que chegamos a uma regionalização do espaço brasileiro, a qual nos ajuda a compreender melhor as contradições agudas que caracterizam nossa história territorial e que se expressam no momento presente. Para tanto, a cartografia temática foi fundamental, pois, a partir dela, buscamos sobrepor informações antes apresentadas e analisadas fragmentariamente.

De acordo com esse caminho analítico, concebemos e confrontamos o Mapa 7, que reúne informações sobre renda média mensal/PEA (em números absolutos)/rede viária e o Mapa 8, baseado no método de clusters e que traz uma tipologia que reúne as variáveis densidade, renda média mensal e taxa de atividade. ${ }^{?}$

7 A largura das barras expressa o perfil de cada grupo: barras à direita indicam que, nessa variável, o grupo está acima da média e, à esquerda, abaixo da média. N é o número de municípios que compõem cada grupo. 
Mapa 7 - Brasil: renda média mensal, PEA e rede viária (federal e estadual)

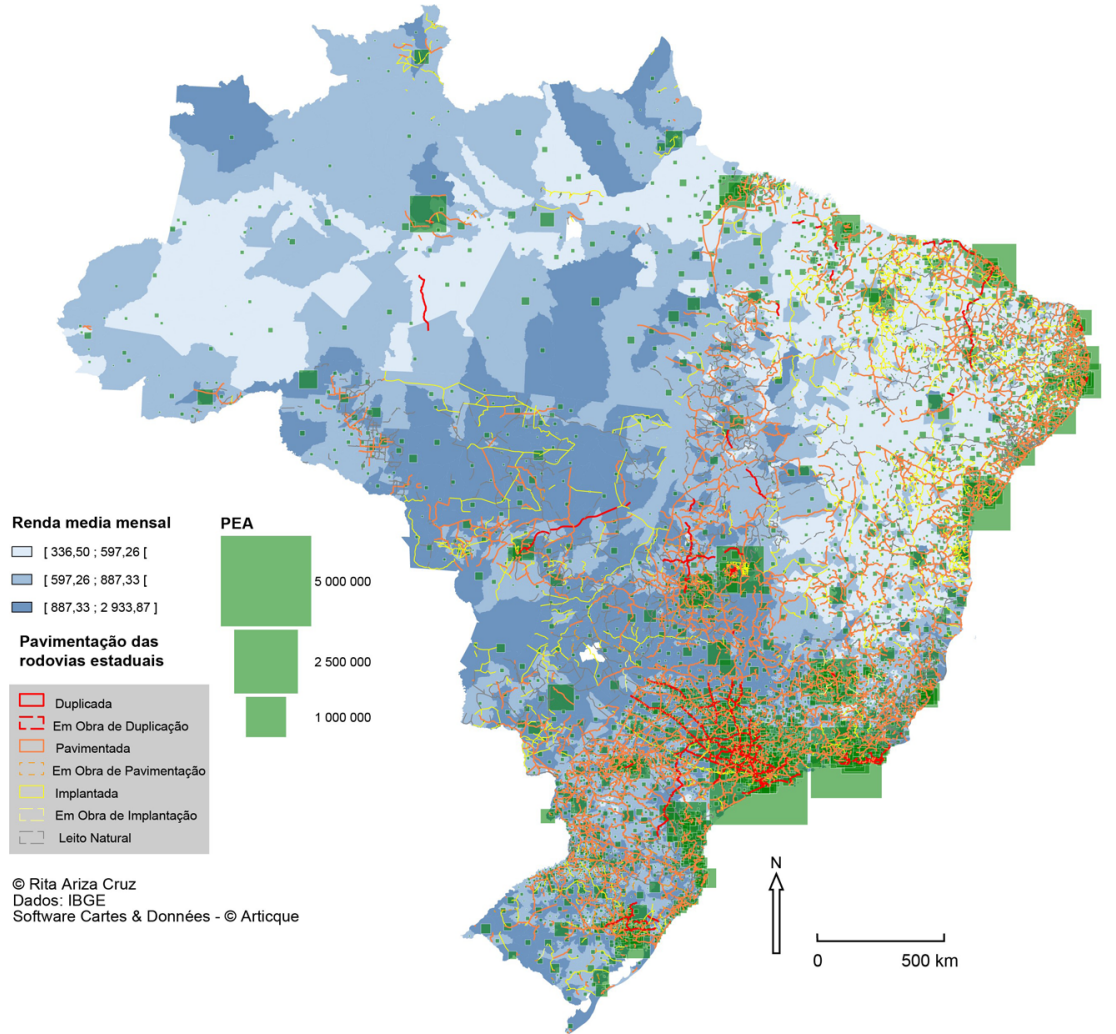

elaboração: Hervé Théry (2020).

Mapa 8 - Brasil: renda média mensal, PEA e rede viária (federal e estadual), tipologia

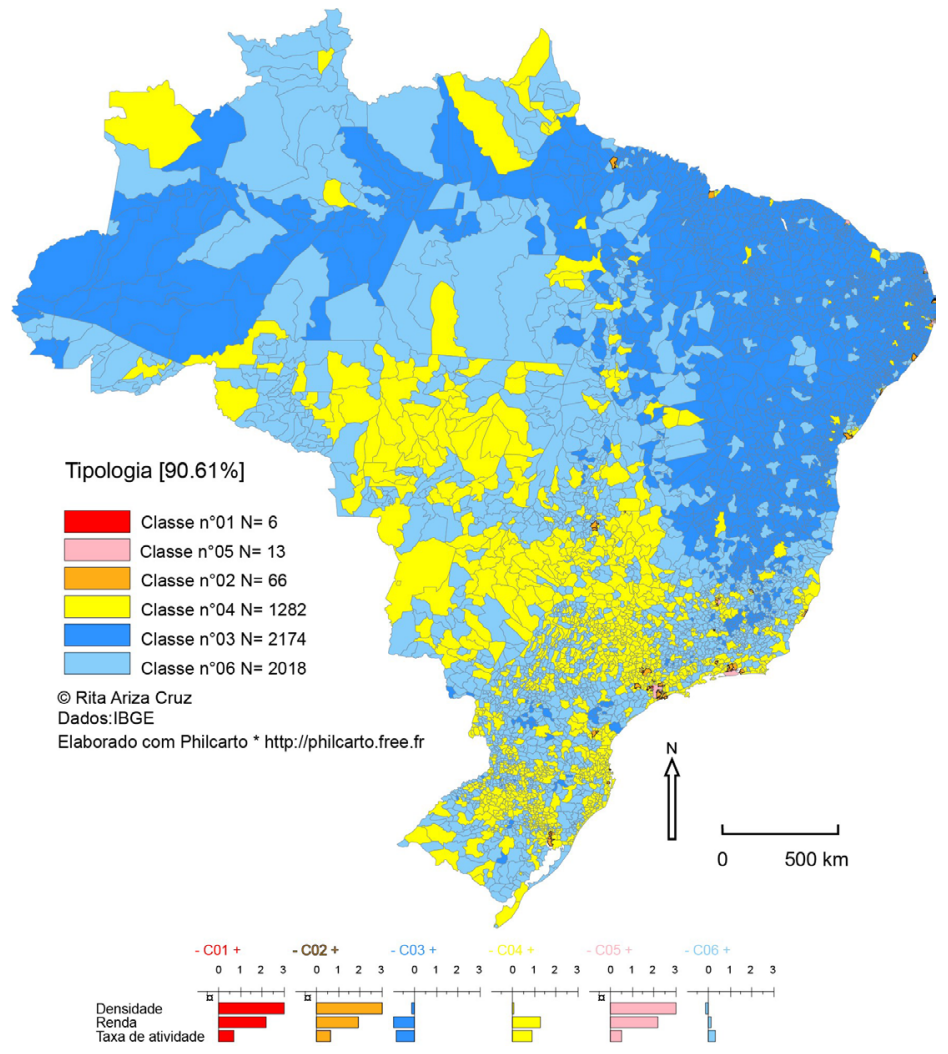


Como se vê, os Mapas 7 e 8 dão uma visão clara da manifestação espacial da desigualdade no território nacional considerando-se as três variáveis primeiramente sobrepostas. A forte concentração da PEA em regiões metropolitanas, com destaque para São Paulo e Rio de Janeiro, é uma expressão, também, da concentração demográfica em geral e da concentração de renda no país assim como da existência de uma rede urbana fortemente hierarquizada. Além disso, enquanto o Mapa 7 evidencia mais claramente uma fragmentação do espaço no sentido leste-oeste, o Mapa 8 aponta as históricas cisões norte-nordeste e sul-sudeste, a que se junta, mais recentemente, considerando melhores indicadores sociais, a região Centro-Oeste.

Nessa busca pela manifestação do desenvolvimento geográfico desigual no território brasileiro, concebemos e elaboramos um último mapa (do qual se desdobram os Mapas 9 e 10), no qual, pelo método coroplético, sobrepusemos densidade demográfica, renda e densidade de rodovias, o que nos conduziu a uma visão complementar à revelada pelos Mapas 7 e 8, permitindo-nos, com base nos "retratos" do território nacional expressos nesses e também nos Mapas 2, 3, 4-A, 4-B e 5, assim como no referencial bibliográfico em que se fundamentou nossa argumentação, chegar a uma proposta de regionalização.

\section{Desenvolvimento geográfico desigual e regionalização do espaço brasileiro}

\section{Mapa 9 - Base}

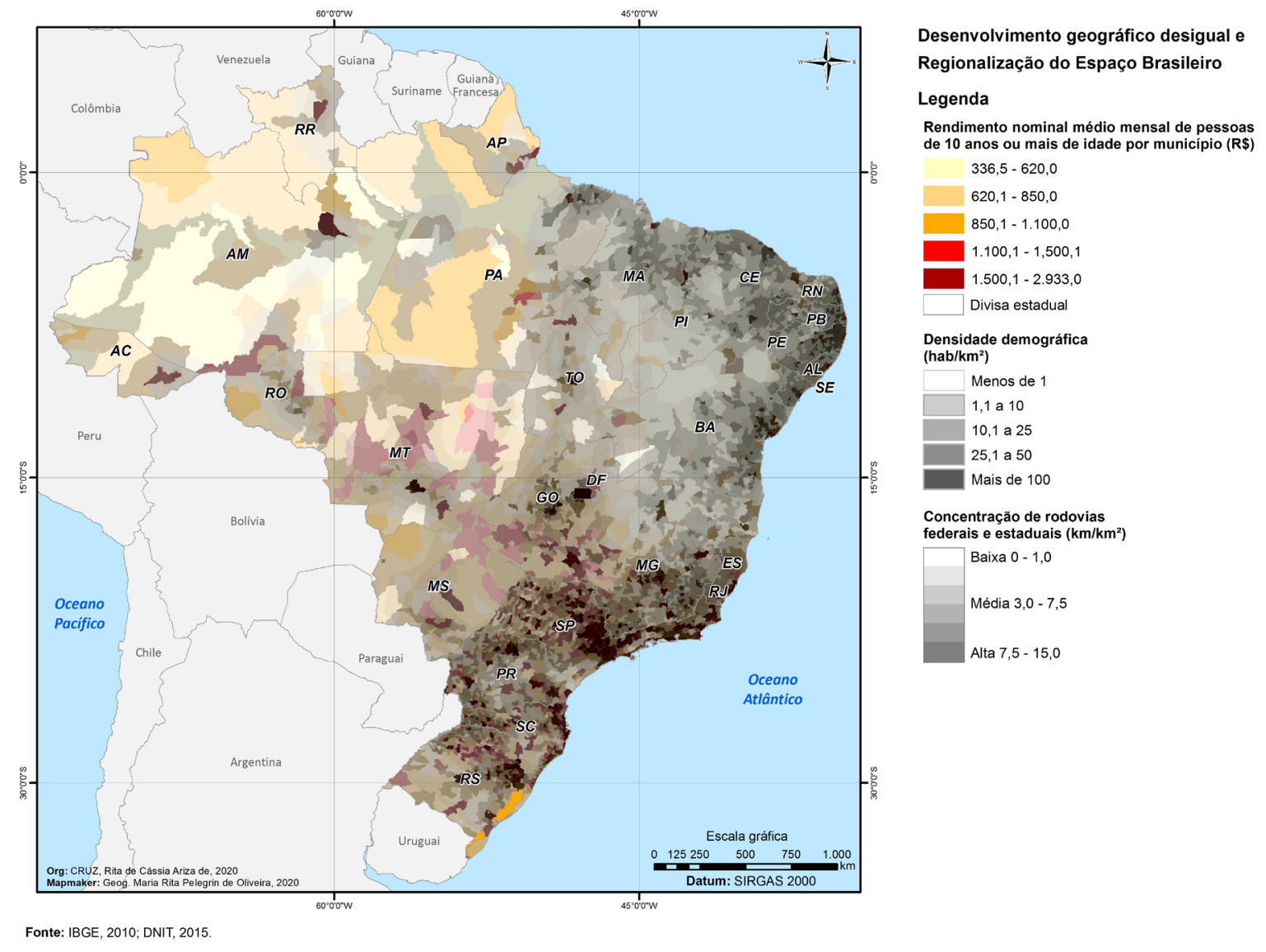


Mapa 10 - Delimitação das regiões

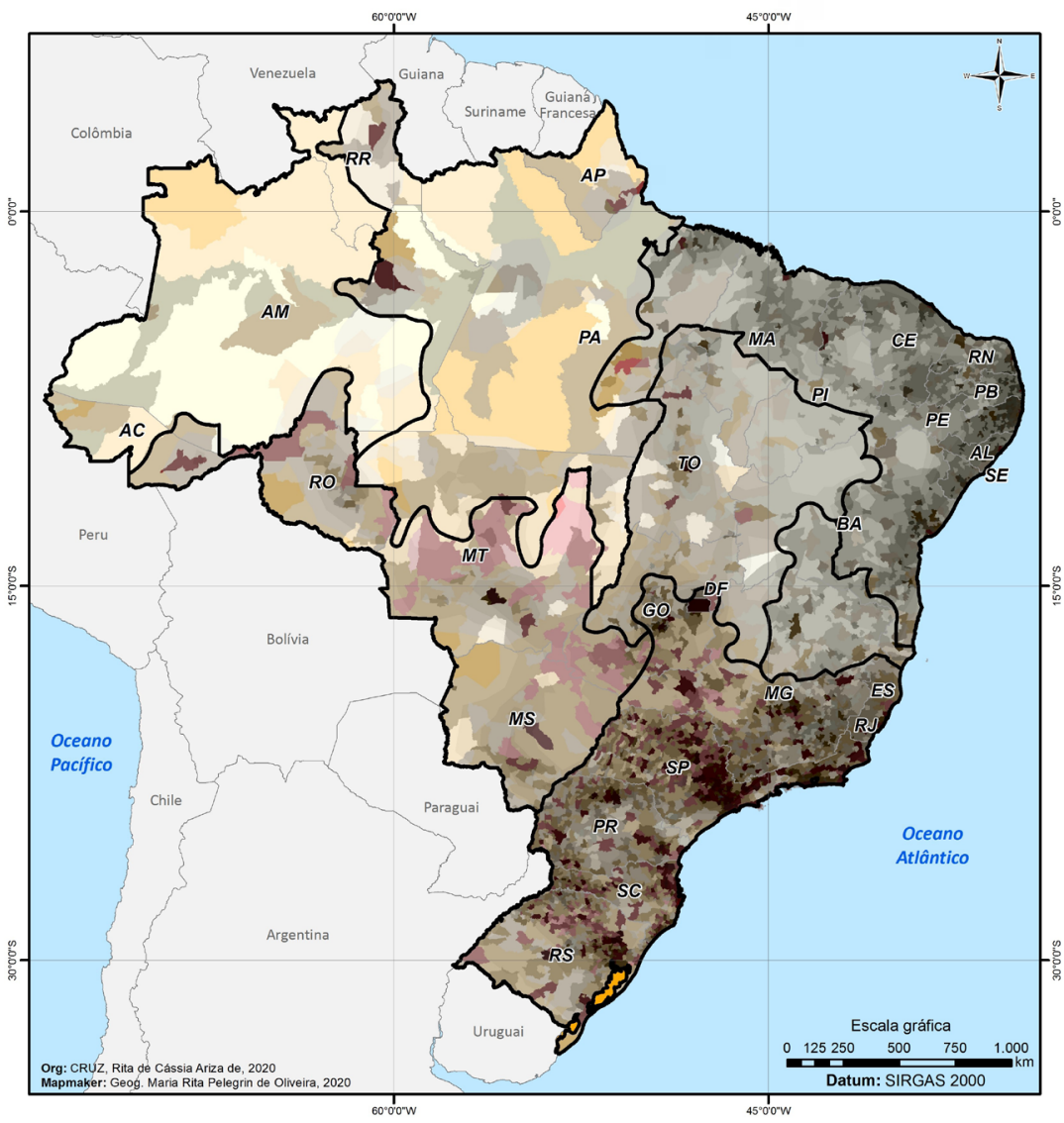

Desenvolvimento geográfico desigual Regionalização do Espaço Brasileiro

Legenda

Rendimento nominal médio mensal de pessoas de 10 anos ou mais de idade por município (R\$) $336,5-620,0$

$620,1-850,0$

$850,1-1.100,0$

$1.100,1-1,500,1$

$1.500,1-2.933,0$

Divisa estadual

Densidade demográfica $\left(\mathbf{h a b} / \mathbf{k m}^{2}\right)$

Menos de 1

$\square, 1$ a 10

10,1 a 25

25,1 a 50

Mais de 100

Regionalização do Espaço Brasileiro (CRUZ, 2020)

Concentraçăo de rodovias federais e estaduais $\left(\mathbf{k m}^{\left.\mathbf{k} \mathbf{k m}^{2}\right)}\right.$

Baixa 0 - 1,0

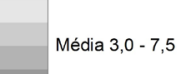

Alta $7,5-15,0$

\section{Mapa 11 - Síntese da divisão regional do Brasil}

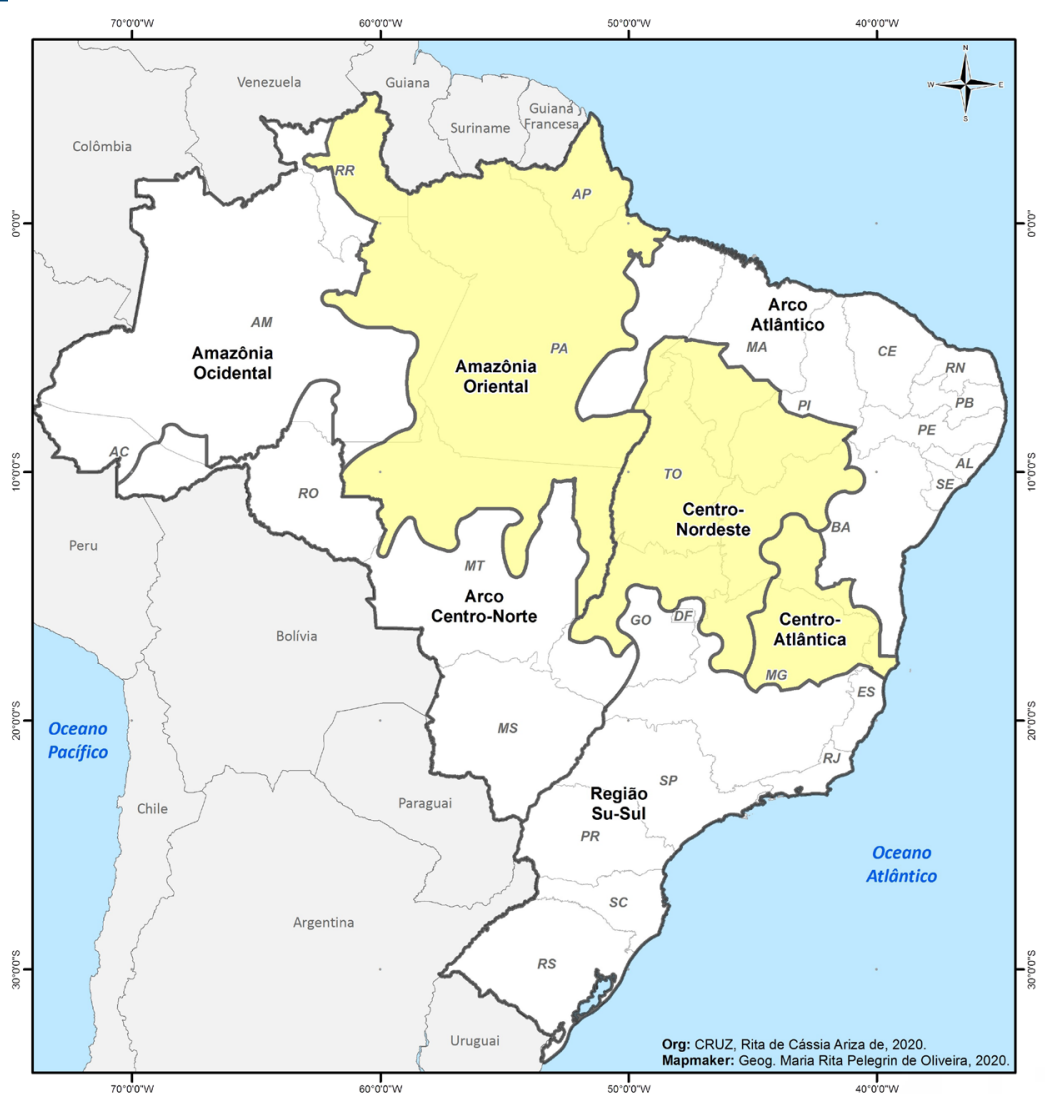

Desenvolvimento geográfico desigual e Regionalização do Espaço Brasileiro

Legenda

Regionalização do Espaço Brasileiro (CRUZ, 2020)

Regiōes de Transição (CRUZ, 2020) Unidades da Federação

América do Sul 
Diferentemente de outras regionalizações e emprestando de Moacir Silva (1939) ${ }^{8}$ e de Aziz Ab'Saber (1965) a ideia de "faixas de transição", entendemos que, ao tratar de aspectos socio-histórico-econômicos, a passagem de uma região para outra também é raramente abrupta, sobretudo quando lidamos com a escala macrorregional.

Concluímos, desse modo, não existirem "dois ou quatro Brasis", mas sete grandes regiões, que são fragmentos de um espaço total, uma totalidade aberta, una e contraditória em movimento, entre as quais três regiões de transição que amalgamam características das grandes regiões com as quais fazem fronteira sem identificar-se integralmente, conforme critérios adotados, com uma ou com outra.

Ressalte-se que não definimos limites precisos para cada uma delas pelo possível deslindamento de dados municipais. Ao contrário, conscientemente definimos esses limites com base nos mapas sínteses construídos para esta análise a partir da interpretação visual possibilitada pela cartografia temática. Quanto à nomenclatura, optamos por designar as regiões com nomes que remetem principalmente a sua posição geográfica no território nacional, evitando supervalorizar uma ou outra de suas respectivas qualidades. Exceção é feita à Amazônia, dada a força histórica desse nome. Por fim, ressaltamos que estamos cientes de que toda macrorregionalização de um território com dimensões continentais como o Brasil implica um alto grau de generalização.

Embora as regiões Norte e Nordeste (conforme divisão oficial do IBGE) partilhem os piores desempenhos em termos de indicadores de renda do país, há uma importante diferença entre elas do ponto de vista da distribuição espacial das forças produtivas e das condições gerais de produção, sendo o Nordeste mais populoso, mais industrializado e mais bem dotado de infraestruturas de circulação que o Norte. Além disso, ambas as regiões abrigam diferenças internas não negligenciáveis. Soma-se a isso o fato de configurações geográficas e padrões de renda aproximarem parte do estado do Pará das porções mais dinâmicas do que conhecemos por Nordeste. Assim, identificamos uma região que forma uma espécie de arco, que abarca fragmentos de todos os estados nordestinos, além de parte do Pará. A essa região chamamos de Arco Atlântico.

O Arco Atlântico abriga porções do espaço geográfico brasileiro de ocupação bastante antiga (séculos XVI e XVII, no caso das localidades mais próximas ao litoral), todas regiões metropolitanas do Nordeste assim como a RM de Belém, destacando-se ainda uma porção do sudeste do Pará que mantém forte relação com o Maranhão, considerando-se a exportação de ferro pelo Porto da Madeira, assim como o processamento, na cidade de São Luís, da bauxita extraída de minas do oeste paraense.

Ao contrário de uma visão histórica - desde a regionalização de André Rebouças, de 1889 -, segundo a qual a Amazônia é vista com uma recorrente homogeneidade, vislumbramos diversas Amazônias, tal como Carlos Walter Porto-Gonçalves, ainda que o caminho analítico percorrido aqui seja diferente do adotado pelo autor. Vemos uma Amazônia Ocidental (grosso modo, porção oeste dos estados de Roraima, Acre e Amazonas), menos densamente ocupada, menos dotada de infraestruturas de circulação rodoviária (havendo que destacar a importância dos cursos

8 Moacir Silva (1939, p. 93) parte da regionalização do Brasil de Delgado de Carvalho, que considera cinco regiões e propõe o desmembramento de alguns estados, entendendo-os como zonas de transição.

9 Entre as áreas nucleares dos domínios morfoclimáticos e fitogeográficos, Aziz Ab’Saber (2003, p. 23) apontou a existência de "áreas de contato e de transição". 
fluviais para a circulação intrarregional) e com piores indicadores de renda, onde não se encontram atividades industriais relevantes na estruturação do espaço regional.

Por outro lado, nos deparamos com "outra Amazônia", amalgamada ao chamado Centro-Oeste, abarcando fragmentos dos estados do Acre (porção leste), incluindo a capital, Rio Branco, todo o estado de Rondônia e uma pequena área ao sul do Amazonas, microrregião de Purus. Essa região está estruturada pela atividade mineradora e pelo agronegócio industrializado, com densidades demográficas maiores, assim como com melhores indicadores de renda, embora a circulação territorial não tenha alcançado aí, até os dias atuais, o mesmo desenvolvimento da região vizinha a leste.

Embora seu indicador de renda o inscreva entre as regiões mais ricas do país, ${ }^{10}$ o CentroOeste (segundo o IBGE) distancia-se do Sudeste e do Sul em termos de concentração de PEA (apenas cerca de 7\% nessa região, contra 43\% e 7\% no Sudeste e no Sul, respectivamente), ${ }^{11}$ de redes de circulação territorial (cerca de 13,4\% da extensão total das rodovias) e de concentração espacial de empresas industriais (Mapas 4-A e 4-B). Por outro lado, também se distancia da Amazônia Ocidental, da Amazônia Oriental e do Centro-Nordeste no que tange ao indicador de renda. Fortemente marcada pelo desenvolvimento do agronegócio, essa região se distingue das circundantes pela industrialização maciça do campo, contraditoriamente acompanhada de uma "urbanização raquítica" (para usar uma expressão de Milton Santos). Chamamos essa região de Arco Centro-Norte.

Ainda na Amazônia, encontramos uma região de transição entre a Amazônia Ocidental e o Arco Atlântico abrangendo todo o Amapá, fragmentos a leste dos estados de Roraima (com a capital Boa Vista) e do Amazonas (com a Região Metropolitana de Manaus), grande parte do Pará e uma faixa a norte do Mato Grosso. A essa região chamamos de Amazônia Oriental. Essa porção do vasto território amazônico é geograficamente mais próxima do Nordeste e do Sudeste (segundo o IBGE) e está mais bem integrada à economia nacional, destacando-se a atividade agropecuária e mineradora. Como uma "região de transição", uma de suas características é a aparente maior heterogeneidade interna, destacando-se contrastes significativos em termos demográficos, de infraestruturas e de redes de circulação.

Regiões de transição chamam atenção para a plasticidade dos processos sociais, que contrariam limites euclidianos e tensionam os estudos regionais. Nessas regiões, as densidades em termos de configurações geográficas são, grosso modo, intermediárias em relação às regiões que lhes são próximas. É o que encontramos também entre as regiões do Arco Atlântico e Su-Sul, onde se mesclam características marcantes de uma e de outra, tal como indicadores demográficos médios e uma relativa densidade das redes de circulação rodoviária, além de indicadores socioeconômicos mais heterogêneos em relação a seu respectivo entorno.

Tais pressupostos nos levaram a identificar outras duas regiões de transição: a que estamos chamando de Centro-Nordeste, bastante extensa, abarcando o estado de Tocantins e fragmentos ao sul dos estados do Maranhão e do Piauí, oeste da Bahia, norte de Goiás, norte de

10 De acordo com a PNAD Contínua 2018, o rendimento médio mensal real da população residente com rendimento no CentroOeste foi de $R$ \$2.440,00, um pouco maior que na região Sul, com $R$ \$2.401,00, e um pouco menor que no Sudeste, o maior do país, com $R \$ 2.563,00$. Norte e Nordeste tiveram rendimentos médios de $R \$ 1.646,00$ e $R \$ 1.412,00$, respectivamente.

11 Com base em dados da Rais (2015) (Fapespa, [2015]). 
Mato-Grosso; e a que chamamos de Centro-Atlântica, territorialmente menor que as outras duas, situada entre o Arco Atlântico, o Centro-Nordeste e o Su-Sul.

A região Centro-Nordeste caracteriza-se por um menor desenvolvimento das forças produtivas em relação às regiões com que faz limite (Arco Atlântico, Centro-Atlântico e Su-Sul), à exceção da Amazônia Oriental. $\bigcirc$ agronegócio da soja e do algodão tem sido responsável por uma rápida e profunda transformação de parte dessa região onde, todavia, os indicadores de renda e as infraestruturas de circulação seguem sendo mais baixos em relação a regiões adjacentes. A única capital de estado nessa região é Palmas.

Já a região Centro-Atlântica tem uma localização geográfica peculiar, na porção oriental do território nacional e entre as duas regiões com os melhores indicadores em termos de desenvolvimento das forças produtivas consideradas nesta análise (força de trabalho, inferida a partir de indicadores demográficos, e rede de circulação rodoviária), assim como melhor rendimento médio mensal. Embora as condições de circulação sejam boas, os indicadores de renda são piores que aqueles encontrados no Arco Atlântico e na região Su-Sul.

Por fim, identificamos (assim como outros autores) que parte da região Sudeste e a região Sul (conforme o IBGE), formam, juntas, uma área densamente povoada, qualitativamente muito mais bem dotada de redes de circulação rodoviária que todas as outras regiões do Brasil, além de abrigar os melhores indicadores de renda. Trata-se da região mais industrializada do país, que concentra a indústria de alta tecnologia (Mapa 4-B) e outras atividades intensivas em conhecimento. Grande parte dela coincide com aquela que Milton Santos chamou de Região Concentrada, mas, segundo nossa interpretação, ela integra parte do estado de Goiás e o Distrito Federal, dados, sobretudo, a densidade das redes de circulação e os indicadores de renda, que a aproximam de estados do Sul e do Sudeste. Ela também coincide parcialmente com a porção de território onde se sobrepõem, na regionalização de Ruy Moreira, as regiões do "Polígono Industrial" e do "Complexo Agroindustrial". Como dito anteriormente, a estamos chamando de região Su-Sul, onde a partícula "su" indica sudeste. A região Su-Sul abriga a única megarregião do país identificada por Lencioni (2015c, p. 11), composta pelas metrópoles de São Paulo e do Rio de Janeiro, uma "forma hibrida da urbanização regional", "com intensa integração produtiva, forte interação com a economia global e grande densidade dos movimentos pendulares". É importante pontuar que a megarregião Rio de Janeiro-São Paulo organiza, em grande parte, toda a região Su-Sul, considerando inclusive que seu raio de influência a extrapola muito.

\section{Considerações finais}

As diferentes regiões brasileiras, compreendidas assim a partir do desenvolvimento geográfico desigual, são o resultado das relações sociais de produção ao longo do tempo histórico, incluindo o presente. Além disso, podem ser compreendidas - tal como fizemos aqui como fragmentos de uma totalidade una, contraditória e em movimento e, por isso mesmo, em permanente transformação.

As linhas divisórias que separam cada região da outra devem ser entendidas apenas como linhas imaginárias, plásticas e flexíveis, pois "a nova divisão territorial do trabalho desfaz e refaz a organização espacial e a cada etapa a desigualdade sócio-espacial é refeita; a regionalização 
é refeita, desfazendo antigas regiões que tiveram existência sob outros processos e condições" (Corrêa, 2001, p. 199).

Finalmente, ressaltamos a importância dos exercícios intelectuais de regionalização, que abrem perspectivas para compreendermos melhor o extenso território brasileiro e suas contradições do passado e do presente, sem fechar as largas portas abertas por todos aqueles que, antes de nós, se debruçaram sobre esse mesmo desafio.

\section{Referências}

AB'SABER, A. Os domínios de natureza no Brasil: potencialidades paisagísticas. São Paulo: Ateliê, 2003.

ANDRADE, M. C. A questão do território no Brasil. São Paulo: Hucitec, 2004.

ARRETCHE, M. Trazendo o conceito de cidadania de volta: a propósito das desigualdades territoriais. In: ARRETCHE, M. (Org.). Trajetórias das desigualdades: como o Brasil mudou nos últimos cinquenta anos. São Paulo: Ed. Unesp/CEM, 2015. p. 193-222.

ARROYO, M. Redes e circulação no uso e controle do território.ln: ARROYO, M.; CRUZ, R. C. A (Org.). Território e circulação: a dinâmica contraditória da globalização. São Paulo: Annablume, 2015. p. 37-49.

BEZZI, M. L. Região: uma (re)visão historiográfica - da gênese aos novos paradigmas. Tese (Doutorado em Geografia) - Instituto de Geociências e Ciências Exatas, Universidade Estadual Paulista, Rio Claro, 1995.

BOSCARIOL, R. A. Região e regionalização no Brasil: uma análise segundo os resultados do índice de desenvolvimento humano municipal (IDHM). In: MARGUTI, B. O.; COSTA, M. A.; PINTO, C. V. S. Territórios em números: insumos para políticas públicas a partir da análise do IDHM e do IVS de municípios e das unidades da federação brasileira. Brasilia: Ipea/INCT, 2017. v. 1. p. 185-208.

CARLOS, A. F. A. Da "organização" à " produção" do espaço no movimento do pensamento geográfico. In: CARLOS, A. F. A.; SOUZA, M. L.; SPOSITO, M. E. B. (Org.).

A produção do espaço urbano: agentes e processos, escalas e desafios. São Paulo: Contexto, 2011. p. 53-73.

CLAVAL, P. Geo-épistémologie. Paris: Armand Colin, 2017.

CORREAA, R. L. Trajetórias geográficas. Rio de Janeiro: Bertrand Brasil, 2001.

CORRÊA, R. L. A organização regional do espaço brasileiro. Geosul, Florianópolis, V. 4, n. 8, p. 7-16, 1989.

DENSIDADE DEMOGRÁFICA. Densidade demográfica 2010. Brasilia, DF: IBGE, [2012?]. Disponível em: https://atlasescolar.ibge.gov.br/images/atlas/mapas_brasil/brasil_densidade_demografica.pdf. Acesso em: 10 mar. 2020. 
EMPRESAS INDUSTRIAIS. Distribuição espacial da indústria 2016. Brasilia, DF: IBGE, [2018?]. Disponível em: https://atlasescolar.ibge.gov.br/images/atlas/mapas_brasil/brasil_distribuicao_industrias.pdf. Acesso em: 10 mar. 2020.

EVOLUÇÃO DA MALHA MUNICIPAL. Brasilia, DF: IBGE, [2018?]. Disponível em: https://atlasescolar.ibge.gov.br/images/atlas/mapas_brasil/brasil_evolucao_malha_municipal.pdf. Acesso em: 10 mar. 2020.

FAPESPA. FUNDAÇÃO AMAZÔNIA DE AMPARO A ESTUDOS E PESQUISAS. População economicamente ativa, segundo Brasil, grandes regiões e unidades da federação, 2011-2015. Belém: Fapespa, [2015]. Disponível em: http://www.fapespa.pa.gov. br/sistemas/para2017/tabelas/9_mercado_de_trabalho/6_populacao_economicamente_ ativa_2011_2015.htm. Acesso em: 10 mar. 2020.

GEIGER, P. P. Organização Regional do Brasil. Revista Geográfica, v. 33, n. 61, p. 25-57, 1964. Disponível em: http://www.jstor.org/stable/40991791?seq=1\#page_scan_tab_ contents. Acesso em: 10 mar. 2020.

GUERRA, A.; POCHMANN, M.; SILVA, R. (Org.). Atlas da exclusão social no Brasil: dez anos depois. São Paulo: Cortez, 2014. v. 1.

GUIMARÃES, F. S. M. Divisão regional do Brasil. Revista Brasileira de Geografia, v. III, n. 2, p. 318-373, 1941.

HAESBAERT, R. Regional-global: dilemas da região e da regionalização na geografia contemporânea. 2. ed. Rio de Janeiro: Bertrand Brasil, 2014.

HARVEY, D. Os limites do capital. Trad. Magda Lopes. São Paulo: Boitempo, 2013.

LAMBERT, J. Os dois Brasis. Rio de Janeiro: Inep/MEC, 1959.

LEFEBVRE, H. Espaço e política. Trad. Margarida Maria de Andrade e Sérgio Martins. Belo Horizonte: Ed. UFMG, 2008.

LEFEBVRE, H. La notion de totalité dans les sciences sociales. Cahier Internationaux de Sociologie, Nouvelle Serie, v. 18, p. 55-77, jan.-juin 1955.

LENCIONI, S. Estado de São Paulo: lugar de concentração da inovação e da intensidade tecnológica da indústria brasileira. In: SPÓSITO, E. S. (Org.). O novo mapa da indústria no início do século XXI: diferentes paradigmas para a leitura das dinâmicas territoriais do estado de São Paulo. São Paulo: Ed. Unesp, 2015a. p. 13-34.

LENCIONI, S. Totalidad y triadas: comprendiendo el pensamiento de Lefebvre. In: MATOS, C.; LINK, F. Lefebvre revisitado: capitalismo, vida cotidiana y el derecho a la ciudad. Santiago, CL: Ril, 2015b. p. 57-77.

LENCIONI, S. Urbanização difusa e a constituição de megarregiões: o caso de São PauloRio de Janeiro. Revista Eletrônica de Estudos Urbanos e Regionais, Rio de Janeiro, v. 6, n. 22, p. 6-15, 2015c. 
LENCIONI, S. Condições gerais de produção: um conceito a ser recuperado para a compreensão das desigualdades de desenvolvimento regional. Scripta Nova, v. XI, n. 245(07), p. 1-11, ago. 2007.

MARKUSEN, A. Região e regionalismo: um enfoque marxista. Espaço $\mathcal{E}$ Debates, v. 1, n. 2, p. 61-99, 1981.

MORAES, A. C. R. Território e história no Brasil. 3. ed. São Paulo: Annablume, 2008.

MORAES, A. C. R. Contribuições para a gestão da zona costeira do Brasil: elementos para uma geografia do litoral brasileiro. São Paulo: Edusp/Hucitec, 1999.

MOREIRA, R. A formação espacial brasileira: contribuição crítica aos fundamentos espaciais da geografia do Brasil. Rio de Janeiro: Consequência, 2014.

MOURA, R. O complexo dialogo entre o urbano e o regional. Revista Brasileira de Desenvolvimento Regional, Blumenau, v. 4, n. 2, p. 5-26, 2016.

MOURA, R.; LIRA, S. A. Aplicação da análise exploratória espacial na identificação de configurações territoriais. Revista Brasileira de Estudos Populacionais, Rio de Janeiro, v. 28, n. 1, p. 153-168, 2011.

PRADO JR., C. Formação do Brasil contemporâneo. São Paulo: Companhia das Letras, 2017.

SANTOS, M. Espaço e método. 4. ed. São Paulo: Nobel, 1997.

SANTOS, M. A natureza do espaço. São Paulo: Hucitec, 1996.

SANTOS, M.; SILVEIRA, M. L. Brasil, território e sociedade no início do século XXI. Rio de Janeiro: Record, 2001.

SILVA, M. M. F. Geografia dos transportes no Brasil. Revista Brasileira de Geografia, Rio de Janeiro: IBGE, v. 1, n. 2, p. 84-96, abr. 1939.

SMITH, N. Desenvolvimento desigual: natureza, capital e a produção de espaço. Rio de Janeiro: Bertand Brasil, 1988.

THÉRY, H.; MELLO-THÉRY, N. A. Atlas do Brasil. 3. ed. São Paulo: Edusp, 2018.

TUNES, R. H. Geografia da inovação: território e inovação no Brasil no século XXI. Tese (Doutorado em Geografia Humana) - Faculdade de Filosofia, Letras e Ciências Humanas, Universidade de São Paulo, São Paulo, 2015. 